\title{
A Discussion of the Power of Science to Complement Ethno+musicological Studies: Insights from Interdisciplinary Musicology
}

Uma discussão sobre o Poder da Ciência para Complementar Estudos Ethno + Musicológicos: Perspectivas de Musicologia Interdisciplinar

Una Discusión del Poder de la Ciencia para Complementar los Estudios Etno-musicológicos:

Perspectivas de la Musicología Interdisciplinaria

Silvia Lazo

\section{Abstract}

In the animal kingdom, competition and hierarchical arrangements relative to members of the same sex are extremely common, with males competing for the top "alpha male" position and females ranked below them. Despite the widespread occurrence of hierarchical self-organization among animals and humans, ethno+musicologists often shy away from phylogenetic inferences and borrowing resources from biology, psychology, and anthropology. Is this a reflection of scholarly bias or a sense of unease with interdisciplinary, indirect, and large-scale data? This paper explores some answers to this question and suggests interdisciplinary connections for both ethnomusicology and musicology through the examination of biological and cultural frameworks with respect to social dominance.

Keywords: Biology. Interdisciplinary Musicology. Social Dominance and Music.
* Ph.D. Musicology/Interdisciplinary Studies, University of Montana, 2013. University of Texas Rio Grande Valley. E-mail: silvia.lazo@utrgv.edu

Recebido em 12/7/2017 - Aprovado em 31/8/2017 http://dx.doi.org/10.5335/hdtv.18n.1.7304 
Figure 1: Raven. Personal Archives.

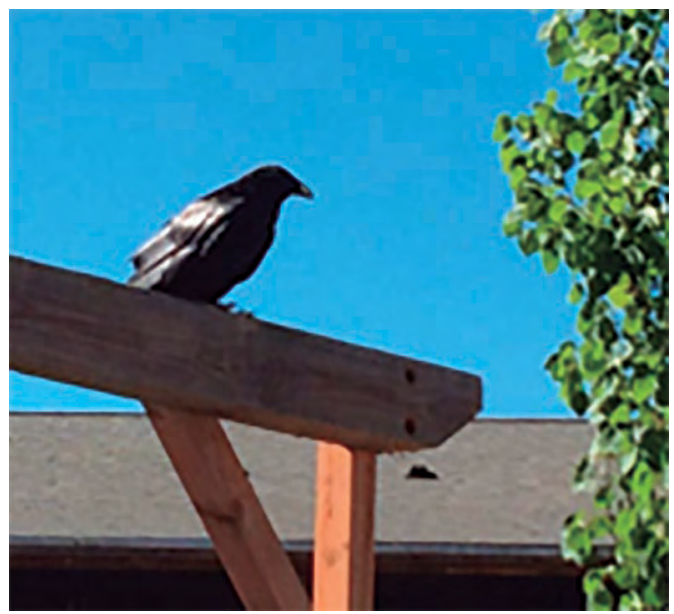

Fonte: arquivo da autora.

Dominance in ravens is not maintained by hormones [as in the male peacock and most other male birds], but by body size. In birds, real size is not easily apparent, because they are enclosed in a thick layer of feathers. The feathers may be fluffed out or depressed, making a bird seem any of a number of sizes. During the initial greeting ceremonies of males, the newcomer to a group flaunts his size, walking slowly and deliberately, strutting with his head held in a grand, self-assertive manner accentuated by gestures.... Approaching a possible rival, the male may forcefully snap his bill and also flash his strikingly white nictitating eye membranes like headlights turning on and off. He walks, as one raven-watcher quipped, "with an air of cockiness that makes him resemble a street though hogging a sidewalk" (HEINRICH, 1999, p. 208).

In the animal kingdom, competition and hierarchical arrangements relative to members of the same sex are extremely common, with males competing for the top "alpha male" position and females ranked below them. Through a "lyrical and scientific" narrative (AMAZON.COM, n.d.), biologist Berndt Heinrich (1999) explains that sociopsychological behaviors common to humans and birds have more than a passing resemblance (HEINRICH, 1999). This and other writings refer us to sets of shared traits that, despite constant media portrayals as exclusively "human," represent widespread tendencies present throughout the animal world. Such physiological, biochemical, and behavioral connections can lead to powerful insights regarding long-term challenges affecting our growing human population, and they should, at times, be investigated as an integrated whole.

\section{You say"ethno-", I say"musicology"}

With a certain dose of amusement, one can read books and articles drawing sharp distinctions between ethno- and musicology and there is, at present, a sense of competition between these two camps. Wearing an interdisciplinary hat, however, one can observe that this dichotomy is unsustainable and has, perhaps, always been far from real. Similarly, in 1992, John Tobby and Leda Cosmides (The Adapted Mind) established two investigative paradigms: the standard social science model (SSSM), on the one hand, which treats human behavior (and the human mind) as a nearly exclusive product of culture, and the integrated causal model (ICM), on the other, which merges cultural and biological considerations (TOBBY; COSMIDES, 1992). Critics were quick to point out the ex- 
tremeness of the dichotomy between SSSM and ICM in scholarly literature and ideological views, a discussion that may be relevant to musicological discussions. Paradoxically, we have recently seen a marked trend on the part of prominent academic programs to nurture a dual degree in ethno+musicology. This may in part be led by a desire to impart a more value-free musicological education, and in part to boost the employment choices of young graduates. Nevertheless, this "dual degree" trend indicates a recognition of interdependence between the disciplines.

From a healthy interdisciplinary perspective, we can recognize the inevitable shortcomings of all scholarship and its respective blind spots. Listening to the feud between musicological fellows, one feels like a friend partaking of dinner with cousins who are inseparable, yet constantly bickering. Having no desire to mediate this "politics of knowledge," I seek only to highlight alternatives that advance "new, integrated music studies," as suggested by Georgina Born (2010). Through such integrated studies, scholarly disciplines can free themselves to explore various connections with affiliated disciplines.

In this paper, I initiate a dialogue between music and psychobiological factors that sheds light on the politics of social dominance, a discussion that is often centered on culture and economics. I begin by describing two scenarios of scholarly production that fit the label, advancing an alternative approach that may enrich previous findings. I conclude with a brief report on the status of women and minorities in the political and academic systems, and the professions of ethno+musicology and related fields, which reflect a persistent pattern of social dominance in the United States.

\section{Elephants, tigers, cheetahs, and lions: referencing animals in social and academic discourse.}

Anthropomorphism (the attribution of human traits to animals) can be found in the literature, music, and religion of numerous peoples around the world. Opposite attributions, such as animism and animalization, are also commonplace. A case in point is Sydney Hutchinson's (2016) Tigers of a Different Stripe, which links animal archetypes to Dominican Republic gender roles and provides insightful perspectives on local gender relations, complicating simplistic (and often racist) media and scholarship portrayals of Latin America as "the" machista culture. Hutchinson first defines the more traditional masculinity of the homem serio:

In traditional rural society, a man's image depended on obtaining the reputation as "serio" or serious, a term that refers to a person who is hard-working, responsible or morally upstanding, and takes care of his or her family, rather than someone lacking a sense of humor. A man might demonstrate his seriedad by showing his own humility through acts of respect for other honorable men, thereby earning confianza (trust); he may also gain honor through his conquest of women, mastery of dominos or cockfighting, or other kinds of rivalries (HUTCHINSON, 2016, p. 32).

She then extends the narrative to the more recent, dissonant masculinity of the tíguere (the tiger; referenced in the title). En- 
veloped in a shrewdness connected to ill repute, the tíguere is characterized as the "king of the streets": "a sort of trickster, adept of wordplay, colorful slang, doublespeak, sartorially resplendent, successful with women (HUTCHINSON, 2016, p. 33).

In Hutchinson's account, the tíguere (along with its feminine counterpart, the tiguera) stems from a system of unequal power relations, in a state of gloomy "neoliberal" economics lacking in job opportunities. In that sense, the tíguere's transgressions are exculpable insofar as they are strategies of resistance and social disobedience-an attempt to reverse elite and global dominance. The diceyness of the tiger underlies this human-animal nature that is at once threatening and understandable: "Betrayal and surprise ornamented with tricks and stories.... [He is] a violent and bloody person, which is what a tiger is in actual nature" (HUTCHINSON, 2016, p. 37).

Hutchinson came across depictions of the tíguere in merengue lyrics (specifically, Maluca Mala's "El tigeraso"), artists' print ads, broadcasts, and interviews. In citing actual cultural references to metaphors used by the locals, she departed from the highly criticized interpretive approach of anthropologist Clifford Geertz in his essay "Deep Play: Notes on the Balinese Cockfight" (GEERTZ, 1973a), in which he conflated his personal observations with those of local interlocutors, creating the false impression that the Balinese themselves interpreted their culture in the same way. Geertz stated his metaphor was "the Balinese reading of Balinese experience" (CRAPANZANO, 1986, p. 73).
Among the many aggravating issues, Geertz implied that the culture as a whole used the cockfight metaphor. The risk of interpretations show the delicate fault lines of both ethnography and history, requiring careful appraisals on the part of educated readers.

Though certainly thought-provoking in itself, Hutchinson's ethnography can be complemented, for example, with elements of demographic history: trends of global population growth, aging, degrees of local technological innovation, exhausted agricultural lands, and "no New World for migration" (KREAGER, 1993, p. 337), all dilemmas of outdated forms of social organization. One could also expand the work by adding a discussion of patterns of global domination, along with potential correlates in the animal kingdom. Accounts of animalism are (perhaps not accidentally?) abundant in studies of musical cultures, including Hutchinson's, wherein she records that the hombre serio is frequently likened by locals to hombre de gallo (a cock of a man) - resulting in several merengue lyrics connected to cockfighting (HUTCHINSON, 2016, p. 32). The connection between biology and culture deserves greater exploration in ethno+musicology.

The lack of attention paid to biogenetic features in humanistic analysis is unsurprising, given the scholars' habits of study, but this may also reflect a sense of unease with interdisciplinary and large-scale data. As Bruno Nettl notes, the birth field of ethnomusicology - earlier, comparative musicology-suffered recurrent hiccups in its search for universals that, in his opinion, "doesn't work anyway; because it was simply direc- 
ted at useless speculation about history and prehistory" (2010, p. 67). The absence of integrative discussion, however speculative, nevertheless entails partiality in intellectual inquiry, leading to unreflective assumptions of correlation-causation.

Heinrich notes that "humans usually have considered themselves to be different and apart from other animals" (1999, p. XVI). Heinrich ponders whether the distinction asserted by humans arises because not all of life's directives are laid out in advance and yet humans, like ravens, engage in imaginative problem-solving tasks and planning. Heinrich continues: "[A]ll animals solve the same age-old problems relating to food, partnerships, sex, shelter, home and caring for their young" (1999, p. XVI). Many species along the evolutionary continuum display emotions, communicate with vocalizations, present preferences of taste and will, manifest a particular personality, have memory, and recognize self and others as well as various objects (HEINRICH, 1999, p. 167). In his inspired account of the parenting of four baby ravens - two males, Goliah and Fuzz, and two females, Lefty and Houdi-Heinrich notes that the males were decidedly more dominant and the females "less confident" (1999, p. 9). As the males vied for the top position, eventually won by Goliah, who frequently displayed erect feathers and a high gaze, the females too competed for a ranked position, albeit subordinate to their male counterparts. Because he was able to assert a permanent superior status, Goliah earned first right of access to carcasses and meals while the others watched and waited. The ravens' story has points of correspon- dence with the "requirements" and display of male dominance in Dominican culture that Hutchinson describes. Might the correlates have psychobiological significance?

\section{Localization versus Generalization}

When Timothy Rice wrote his prominent article "Toward the Remodeling of Ethnomusicology" (1987), he intended to provide an updated, balanced, comprehensive disciplinary model based on Geertz's The Interpretation of Cultures: "How do people historically construct, socially maintain, and individually create and experience music?" (1973b, p. 473).

Bruno Nettl, on the other hand, subscribed to the notion that ethnomusicology indulges in theoretical and methodological open-endedness relative to other fields, and that this trait is at once disquieting and useful: "I' $m$ astonished that a society with such a vague notion of what it includes [research, study, and performance of music in all historical periods and cultural contexts] can have been so successful-or perhaps the vagueness caused its success" (2010, p. 62).

Despite Nettl's confident statements and Rice's call for a unified methodological model, both ethno+musicologists tend to favor cultural explanations for social dominance, overlooking psychobiological ones. A study conducted by Christopher Waterman on the imaginary construction of a Pan-Yoruban tradition and identity is another example of Marxist-based research that could be broadened by psychobiological studies. As Waterman describes the hierarchical relationship between performers in a 
market-driven Yoruban economy, he notes the position of a leader "clearly distinguished from, and positionally defined by, his subordinates" (1990, p. 373):

Traditional principles of social hierarchy are vividly represented by the stylized behavior of wealthy celebrants, who press paper money to the sweaty forehead of the band leader. The leader or "captain" is invariably a praised singer, who inserts relevant biographical data into formulaic patterns laced with "deep" Yoruba proverbs, and, as I have described elsewhere, takes most of the money. The social distinction between captain and band boys, leader and chorus, individual call and communal response, is also encoded in apparel and spatial relationships. Subordinate musicians stand behind or flank the band captain (1990, p. 373).

A general review of global statistics and understandings on matrilineality, political and economic supremacy, warfare, and violent conflict show that the overwhelming scale of male dominance is such that it borders on universal normativity, although anthropologist Christopher Boehm concedes that the characterization "widespread" is sufficiently strong (1993, p. 250). ${ }^{1}$ Despite this fact, Waterman argued for a "relational and conjunctural cultural identity" that might bear "relevance to the way we represent the relationship of tradition and modernity in ethnomusicology" (1990, p. 377). Missing from Waterman's account is the calculation of self-organizing factors beyond cultural and economic determinants, namely, innate or biochemical dispositions to aggression and dominance. Although primate aggression is still under study, the question of what causes social dominance turns Waterman's finding on its head, making economic ranking a long-term effect rather than a cause of stratification. Further, might there be hierarchies of senses (e.g., sound, vision, taste, movement) or instruments in some cultural expressions? For these reasons, as mentioned, although localized studies can be beneficial, they can also limit our understanding and consequently our everyday actions. Some comparisons and generalizations, especially in a world that is similarly unequal in various ways, are still important.

\section{Are humans a despotic species?}

Scientific findings from the fields of biology, psychology, and anthropology have much to say about human behavior and the construction of a hierarchical social order. These fields have introduced questions combining cultural programming and phylogenetic inference. In African apes, our closest primate relatives, and in other species, dominance is strongly correlated with both reproductive success and access to resources.

Christopher Boehm's "Egalitarian Behavior and Reverse Dominance Hierarchy" (1993) is a fascinating article, whose highlights I will outline but by no means exhaust. In his proposal of a preliminary "theory for egalitarian behavior" that acts to reverse dominant hierarchical authority, Boehm traces purposive levelling mechanisms that appeared in the first prehistorical human groups (48 cases selected), demonstrating "a continuum from animal societies to economically developed states" (DUPRÉ, 
1993, p. 242). To curb overly aggressive tendencies of certain leaders, various groups, including the Mbuti Pygmies, Eskimos, and Navajos, periodically employed a number of levelling strategies: pressure coming from public opinion, criticism, ridicule, disobedience, deposition (replacement), desertion, exile, and execution. Boehm argues that this is due to the existence of a general scheme of motivated actions rooted in an egalitarian ethos that disapproves of hierarchies. Further, he notes that these "reverse dominance" policies are more frequently seen in small units ("just a few hundred persons"), ensuring a distributed leadership (BOEHM, 1993, p. 236).

Boehm's study also provides for additional conditions of group subordination (charismatic leadership, internal and external threats, etc.), transitions between power structures, characteristics of consensus-oriented communities, phylogenetic considerations (connections with African apes), and coevolved genetic dispositions. In the main, however, Boehm persuasively dislodges the scholarly favoritism toward causality based on "environmental variables and subsistence patterns" that are prevalent in cultural studies (1993, p. 239). The study moves away from the view of human hierarchical determinism in that the first human societies "began in opposition to its animal base," and thus "preceded inegalitarian forms of political organisation" (DUPRÉ, 1993, p. 242). Accordingly, our emphasis on sociopolitical formation should be broadened to entertain a conversation between biological, exogenic, and unreflective causes along with rational choice.
In the field of psychology, the jury is still out when it comes to male dominance, with explanations ranging from biological (e.g., testosterone) to cultural (e.g., religious upbringing, perception of strength based on size, voice, and face) to deeply rooted psychological causes (collective psychological disorder): "What sane species would treat half of its members - and the very half which gives birth to the whole specieswith such contempt and injustice?" (TAYLOR, 2012). The possibility of engaging with the central issue of male dominance in an integrative manner seems to offer an opportunity for a balanced debate.

\section{Conclusion}

In this brief essay, I have sought to bring together some interdisciplinary perspectives that can expand the scope of ethno+musicological studies in general and our understandings of social dominance in human societies in particular. My feeling is that interdisciplinarity, once dismissed as lowly, generalist scholarship, may occasionally be a useful and important tool for promoting unique dialogues and content. As Roland Barthes observed, "Interdisciplinarity consists of creating a new object that belongs to no one" (CLIFFORD, 2010, p. 1). I intentionally use the suggestion of occasional interdisciplinarity to avoid what Susanne Langer already described as a persistent desire on the part of scholars to pursue all promising ideas (grande idee) to solve all of our problems (GEERTZ, 1973c). ${ }^{2}$ That is to say that research is often contingent. 
In Nettl's Elephant (ha!), Bruno Nettl recollects his early career as a pioneer ethnomusicologist by drawing an uncomfortable analogy between a Nova TV program, "Cheetah among the Lions," and his professional status in a majority-musicological department. He remarks that, in the end, he and his colleagues saw themselves as joint contributors to the field of music. He further located ethnomusicology as belonging to the umbrella of "musicology," encompassing all that is historical and cultural, as well as "belong[ing] to other fields" (NETTL, 2010, p. 104).

It is in this "belonging" that the practice of interdisciplinarity can make ethno+musicology at times less orthodox and more capacious. Interdisciplinarity can provide a framework for what to consider when observing ourselves and others "in music," and it can tell us more about who we are and how to better dislocate ourselves professionally. I conclude with an overview of standing hierarchical distribution of persons in US political and faculty systems, and in ethno+musicology and associated fields, hoping that we might reflect on our better selves to bring an alternative egalitarian community to fruition.

\section{U.S.Political Structure}

45 Presidents: $100 \%$ Male, $97 \%$ White 48 Vice-Presidents: $100 \%$ Male, $100 \%$ White $115^{\text {th }}$ Congress (2017): $80.4 \%$ Male, $81 \%$ White Source: Center for American Women and Politics, 2017.

Figura 2: U.S. Department of Education

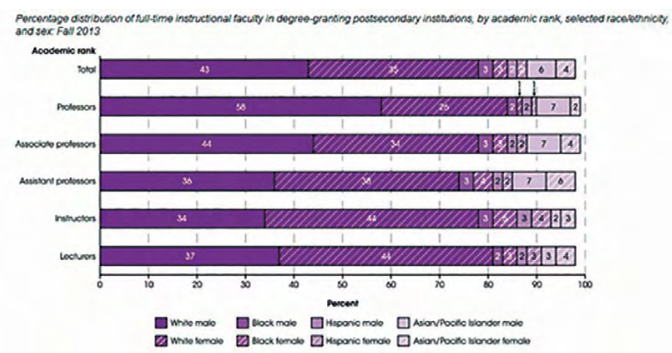

Source: National Center for Education Statistics, 2016.

Tabela 1: Society for Ethnomusicology

\begin{tabular}{l|c|c|c|c}
\cline { 2 - 4 } & 2002 & 2008 & 2014 & $\begin{array}{c}\text { US Population } \\
\text { (Census 2010) }\end{array}$ \\
\hline Euro-American & $82.7 \%$ & $82.8 \%$ & $75.5 \%$ & $61.3 \%$ \\
African American & $4.1 \%$ & $5.3 \%$ & $4.8 \%$ & $13.6 \%$ \\
Hispanic American or Latino & $4.2 \%$ & $5.1 \%$ & $6.4 \%$ & $16.3 \%$ \\
American & & & & \\
Asian American or Pacific Islander & $7.3 \%$ & $5.8 \%$ & $6.9 \%$ & $5.6 \%$ \\
American & $0.9 \%$ & $1.8 \%$ & $1.5 \%$ & $2.5 \%$ \\
Middle Eastern American & $4.1 \%$ & $1.8 \%$ & $3.1 \%$ & $1.7 \%$ \\
Native American or American & $51.7 \%$ & $51.4 \%$ & $52.2 \%$ & $50.8 \%$ \\
Indian & $48.3 \%$ & $48.6 \%$ & $46.5 \%$ & $49.2 \%$ \\
Female & -- & -- & $1.3 \%$ & - \\
Male & & &
\end{tabular}

Source: The Society for Ethnomusicology, 2015. 
Tabela 2: American Anthropological Association

\begin{tabular}{l|c|c|c|c}
\hline & Male & Female & \multicolumn{2}{|c}{ Totals } \\
\hline White & 2983 & 3797 & 6780 & $70.0 \%$ \\
Black or African & 88 & 137 & 225 & $2.3 \%$ \\
American & 268 & 211 & 479 & $4.9 \%$ \\
Latino or Hispanic & 238 & 212 & 450 & $4.6 \%$ \\
Asian or Pacific Islander & 167 & 205 & 372 & $3.8 \%$ \\
Two or More Racial & 58 & 89 & 147 & $1.5 \%$ \\
Identities & & & & \\
American Indian, Native & 592 & 641 & 1233 & $12.7 \%$ \\
Alaskan, 1st Nation & 4394 & 5292 & 9686 & \\
Prefer Not to Answer & 596 & \\
Total & & & \\
\hline
\end{tabular}

Source: LIEBOW, 2017.

Tabela 3: American Musicological Association

\begin{tabular}{l|c|c}
\cline { 2 - 3 } & Responses & Percentage \\
\hline White & 975 & $89.7 \%$ \\
Black/African-American & 12 & $1.1 \%$ \\
Latino & 35 & $3.2 \%$ \\
Asian & 38 & $3.5 \%$ \\
Female & 566 & $51.2 \%$ \\
Male & 536 & $48.5 \%$
\end{tabular}

Source: American Musicological Association, 2017.
Figura 3: American Historical Association

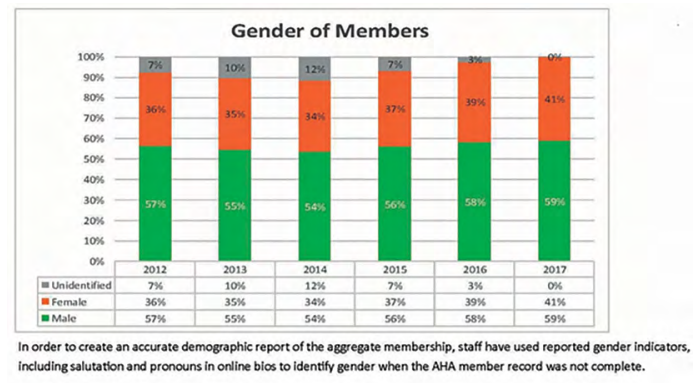

Figura 4: Source: TOWSEND, 2017

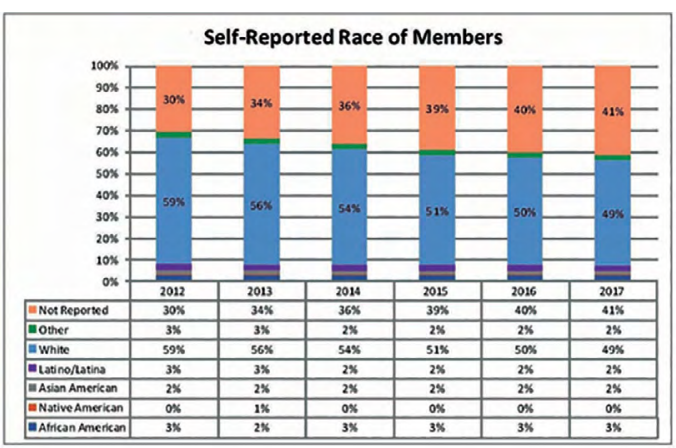

Source: TOWSEND, 2017.

Figura 5: Society for Music Theory

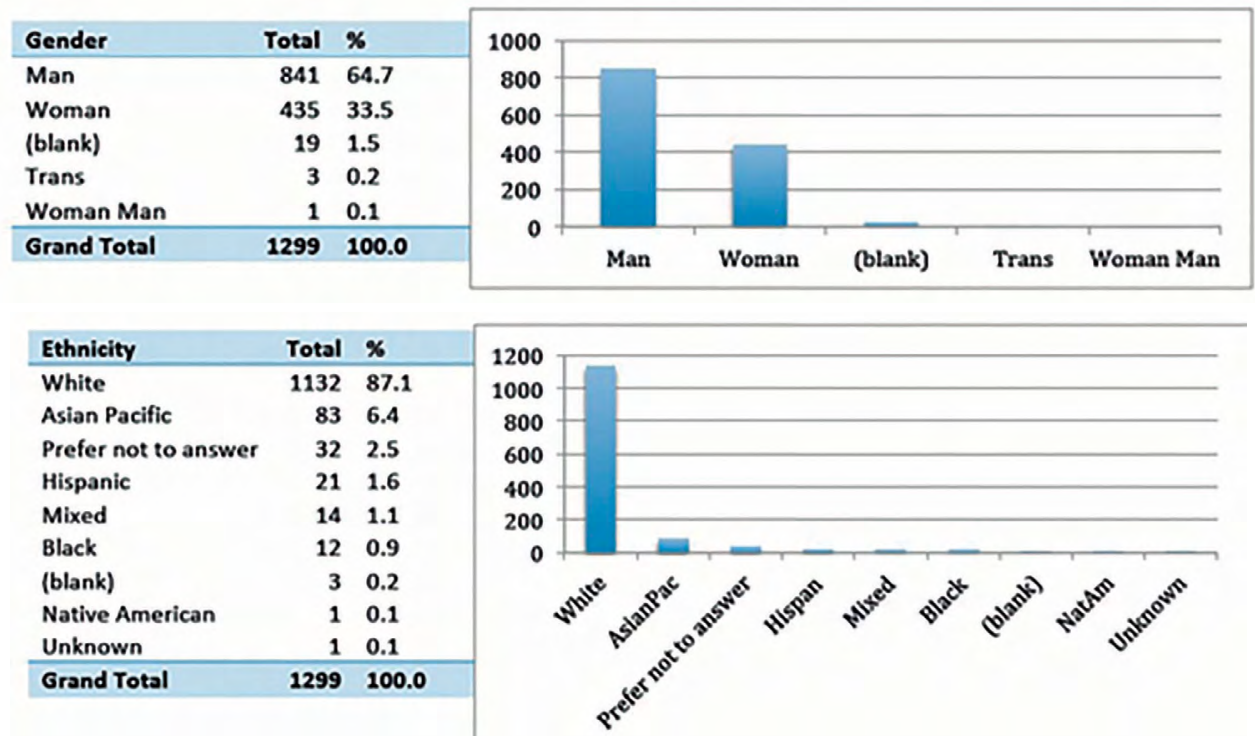

Source: Society for Music Theory, 2016. 


\section{Resumo}

No reino animal, a concorrência e os arranjos hierárquicos relativos aos membros do mesmo sexo são extremamente comuns, com os homens competindo pela posição "alfa masculina" superior e as mulheres classificadas abaixo deles. Apesar da ocorrência generalizada de auto-organização hierárquica entre animais e seres humanos, os etno + musicólogos muitas vezes se afastam das inferências filogenéticas e dos recursos emprestados da biologia, psicologia e antropologia. Isso é um reflexo do viés acadêmico ou uma sensação de mal-estar com dados interdisciplinares, indiretos e em grande escala? Este artigo explora algumas respostas a esta questão e sugere conexões interdisciplinares para a etnomusicologia e a musicologia através do exame de estruturas biológicas e culturais em relação à dominância social.

Palavras-chave: Biologia. Dominação e música. Musicologia interdisciplinar.

\section{Resumen}

En el reino animal, la competencia y los arreglos jerárquicos relativos a los miembros del mismo sexo son extremadamente comunes, con los hombres compitiendo por la posición "alfa masculina" superior y las mujeres clasificadas debajo de ellos. A pesar de la ocurrencia generalizada de autoorganización jerárquica entre animales y seres humanos, los etno + musicólogos muchas veces se alejan de las inferencias filogenéticas y de los recursos prestados de la biología, la psicología y la antropología. ¿Es un reflejo del sesgo académico o una sensación de malestar con datos interdisciplinarios, indirectos y en gran escala? Este artículo explora algunas respuestas a esta cuestión y sugiere conexiones interdisciplinares para la etnomusicología y la musicología a través del examen de estructuras biológicas y culturales en relación a la dominación social.

Palabras clave: Biología. Dominación y música. Musicología interdisciplinaria.

\section{Notas}

1 "Even though I have employed the notion of 'universal' in proposing a general theory [for human hierarchical self-organisation], I would happily settle for 'widespread'" (BOEHM, 1993, p. 250).

2 Geertz is referring to Suzanne Langer's "Grande Ideé" in Philosophy in a New Key ${ }^{(1942) .}$

\section{Bibliography}

AMAZON.COM. Summary of Mind of the raven: investigations and adventures with wolf-birds, by Bernd Heinrich. Available at: https:/ / www. amazon.com/Mind-Raven-Investigations-Adventures-Wolf-Birds/dp/0061136050. Accessed on July 1, 2017.

American Musicological Association. Newsletter. Summary Report from the AMS Demographic Survey 2017. Available at: <www.ams-net.org/newsletter/ AMSNewsletter-2017-2. pdf $>$. Accessed on July 22, 2017.

BOEHM, Christopher. Egalitarian behavior and reverse dominance hierarchy. Current Anthropology, v. 34, n. 3, p. 227-254, 1993.

BORN, Georgina. For a relational musicology: music and interdisciplinarity, beyond the 
practice turn. Journal of the Royal Music Association, v. 135, n. 2, p. 205-243, 2010.

Center for American Women and Politics (CAWP). Rutgers University. Pew Research Center. Gallery of US Presidents and Vice-Presidents, 2017. Available at: <http:/ / www. cawp.rutgers.edu/>. Accessed on July 1, 2017.

CLIFFORD, James. Introduction: Partial truths. In: CLIFFORD, James, and MARCUS, George (eds.). Writing culture. 2. ed. Los Angeles: University of California Press, 2010, p. 1-20.

CRAPANZANO, Vincent. Hermers' dilemma: the masking of subversion in ethnographic description, in Writing Culture. In: CLIFFORD, James, and MARCUS, George (eds.). The poetics and politics of ethnography. Los Angeles: University of California Press, 1986, p. 51-76.

DUPRÉ, Marie-Claude. Reply to Boehm: egalitarian behavior and reverse dominance hierarchy. Current Anthropology, v. 34, n. 3, p. 242, 1993.

GEERTZ, Clifford. The interpretation of cultures: selected essays. New York/USA: Basic Books, 1973.

HEINRICH, Bernd. Mind of the raven: investigations and adventures with wolf-birds. HarperCollins, E-book, 1999.

HUTCHINSON, Sydney. Tigers of a different stripe: performing gender in Dominican music. Chicago: University of Chicago Press, 2016.

KREAGER, Philip. Review: The changing case for demographic moderation. Current Anthropology, v. 34, n. 3, p. 334-338, 1993.

LIEBOW, Ed. Demographics as of December 31, 2016. E-mail June 28, 2017.

MEHTA, Vinita. Are alpha males a myth or a reality? Head Games blog entry, Dec. 4, 2014. Available at: <https://www.psychologytoday.com/blog/head-games/201412/are-alpha-males-myth-or-reality $>$. Accessed on July 1, 2017.

National Center for Education Statistics (2016). The Condition of Education 2016. (NCES 2016144). Characteristics of Postsecondary Faculty.
Available at: <https://nces.ed.gov/fastfacts/ display.asp?id=61>. Accessed on July 22, 2017.

NETTL, Bruno. Nettl's elephant: on the history of ethnomusicology. Chicago: University of Illinois Press, 2010.

O'CONNOR, Lynn. Male dominance and female depression: based on ideas? Our Empathic Nature blog entry. Dec. 3, 2012. Available at: <https:/ / www.psychologytoday.com/blog/ our-empathic-nature/201212/male-dominance-and-female-depression-based-ideas $>$. Accessed on July 1, 2017.

RICE, Timothy. Toward the remodeling of ethnomusicology. Ethnomusicology, v. 31, n. 3, p. 469-488, Autumn, 1987.

Society for Music Theory. SMT Demographic Report. October 2016. Available at: <https:// societymusictheory.org/administration/demographics/charts>. Accessed on July 22, 2017.

Society for Ethnomusicology. SEM 2014 Membership Survey Report. SEM newsletter (Spring 2015). Available at: <http://c.ymcdn. com/sites/www.ethnomusicology.org/resource/resmgr/Newsletters/SEMNL49-2.pd$\mathrm{f}$ ?hhSearchTerms $=\% 22$ membership+and +survey $\% 22>$. Accessed on July 22, 2017.

TAYLOR, Steve. "Why men oppress women." Psychology Today, August 30, 2012. Available at: <https://www.psychologytoday.com/ blog/out-the-darkness / 201208/ why-men-oppress-women>. Accessed on July 9, 2017.

TOBBY, John, and COSMIDES, Leda. The adapted mind. Oxford: Oxford University Press, 1992.

TOWNSEND, Liz. American Historical Association. Demographics of AHA Membership. E-mail June 29, 2017.

WATERMANN, Christopher. Our tradition is a very modern tradition: popular music and the construction of Pan-Yoruba identity. Ethnomusicology, v. 34, n. 3, p. 367-379, Autumn, 1990. 